\title{
Alternative routes to healing in Bangladesh
}

\section{Michael Radford}

Consultant Psychiatrist, Birmingham \& Solihull Mental Health Trust; Honorary Senior Lecturer, Birmingham Medical School

$$
\text { Then }
$$

he mission to find 'the secret of the village' is one attraction of engaging in mental health services in Bangladesh. O ver the last 15 years much attention in world psychiatry has been given to the fairly robust finding that the prognosis of people with established and severe mental illness is better in 'developing countries' than in 'developed' ones (e.g. World Health Organization, 1979; Leff et al, 1990; Jablensky et al, 1992). Earlier assumptions that 'developing' is a simple variable were almost certainly a result of racist ignorance (Kulhara, 1994). D eveloping countries are not homogeneous. The variation in mental health outcomes seems to be clearer in more remote villages and tribal areas (Chatterjee et al, 2003), especially those that have less contact with Western (colonial) models of psychiatry and ways of life. More studies on this topic across a wider range of rural and urban settings would have much to offer. Is there something poisonous that comes with lots of expensive services? $\mathrm{r}$ is there something missing?

\section{Determinants of prognosis}

Many efforts have been made to identify the possible reason or reasons for such findings. Most reviewers emphasise the particular benefits for long-term mental health of extended family systems (see Thara et al, 2004, for a recent overall review). Is this nostalgia for an age when life seemed simpler, before the post-modern era? Alternative explanations are still being advanced: for example, Peet (2004) recently postulated dietary differences between 'developed' and 'underdeveloped' countries.

Major criticisms of the literature on mental health outcomes in different cultures include the failure to understand that there are important differences within cultures, as well as a lack of knowledge both of what they might be and of how the sub-cultural benefits are mediated (Edgerton \& Cohen, 1994). 'The danger of not pursuing the subject of epidemiology in crosscultural settings in its full complexity is that the findings of studies will not be readily translated into preventative programmes and nor will they inform planners of health services' (Bhui, 2001).

Many years ago there were warnings that the unchallenged hegemony of Western models may damage the pre-existing 'alternative' healing mechanisms already present in South Asia (Higginbotham \& Marsella, 1988). H owever, there are abuses of people with mental illness within every system and each has something to learn from the others. Recently some evidence has been published that it is the presence of psychiatric pluralism (the easy availability of religious, indigenous and allopathic practice) that may be the beneficial factor in the superior prognosis in the subcontinent (H alliburton, 2004).

W ithin Western mental health services, groundbreaking findings in Australia started to document that better outcomes can be achieved in applying a 'recovery' model (Tooth et al, 1997). The point being made in such literature is to emphasise the validity of patient experience and the importance of personal growth. In thinking about progno sis in villages or anywhere else, it is necessary to distinguish between what can be called 'healing' and what might be called 'curing': a 'cure' is the restoration of 'part functioning' (Lewis, 1953), whereas 'healing' can be used to refer to the recovery of wholeperson functioning and inclusion in valid social and family roles (on these key conceptual issues see Radford, 2000). The early transcultural studies by the World H ealth $O$ rganization looked at symptoms as an index of prognosis. In major mental illness, symptoms can come and go, depending on the level of stress as well as the presence of cure. Alternative practices may be better than allopathic methods at encouraging healing processes. The techniques associated with 'early-intervention teams' in England also seem associated with better prognosis. This evidence is concordant with the suggestion that 'psychiatric pluralism' of some kind has important benefits, and that sharing experiences of non-reductionist ways of working could lead to a better understanding in a holistic sense - of the processes of healing.

\section{The Bangladeshi experience}

O bservations of the treatment of people with psychiatric illness by myself and others in the Bangladeshi Mental Health Association (BMHA) have recently involved looking over the shoulders of 'village doctors'. We were told many stories relating to the behaviour of people with mental illness on repeated visits to a wide variety of villages. The village effect was illustrated in various ways. People in villages appeared to need smaller doses of medication to control symptoms of mental illness and some people with related behavioural problems were more disturbed when moved to the city. Their condition improved when they moved back to the village. In casual visits to villages it was usual to hear denials of chaining or tying. We were particularly interested to find examples of this practice, because it is often quoted as a counterexample to the benefits of rural life.
Recently some evidence has been published that it is

the presence of psychiatric

pluralism (the easy availability of religious,

indigenous and allopathic practice) that may be the beneficial

factor in the

superior prognosis in the

subcontinent.

$$
\begin{array}{r}
\text { People in villages } \\
\text { appeared to need } \\
\text { smaller doses of } \\
\text { medication to } \\
\text { control symptoms } \\
\text { of mental illness } \\
\text { and some people } \\
\text { with related } \\
\text { behavioural } \\
\text { problems were } \\
\text { more disturbed } \\
\text { when moved to } \\
\text { the city. Their } \\
\text { condition } \\
\text { improved when } \\
\text { they moved back } \\
\text { to village. }
\end{array}
$$


There is one national mental hospital in Bangladesh, which was opened in 1971 to replace the facility in West Pakistan after the independence war. After a World Health $O$ rganization seminar in the early 1980s, it was decided not to commission any more, but to establish beds at regional medical schools for acute admission. There are no other long-stay facilities. In a somewhat isolated $\mathrm{H}$ indu tea pickers' settlement was a man with a history of recurrent mania who was taken repeatedly to the regional in-patient centre for the purpose of containment and to receive haloperidol. This man remained fully integrated in the life of his village, perhaps because his condition was seen as a visitation for which he was not to blame. Also, he was an important member of the community, for he was the only person who could fix the village pump. Those in isolated villages are inclined to believe more in passing jinns (genies) than in passing genes.

The main method of (occasional) contact that Bangladeshi psychiatrists have in villages is by holding 'camps'. A visit is advertised by word of mouth; people gather and wait for hours with their sick relatives. $0 \mathrm{n}$ one such occasion, when a camp was held in a remote tribal area, the border police came to check what we were doing. At the same camp three men in chains were brought by their wives or mothers. They had not been thrown out of the community and, unlike what would have happened if they had been confined in the national mental hospital, they had carers who could speak their language and cook their food; and they would be released when they were more settled. 0 ne was sitting with his wife and children, two of whom were conceived after the chains were applied. Women are more likely to be tied with thin ropes. There were two such women seen on this day who answered to the eighteenth-century descriptions of 'raving madness'.

Hearing of our wish to see improvements in community services, two women were referred by journalists to the BMHA when other services were unable to engage them. We needed a police escort to bring one to the service, because she had run into trouble with the village authorities, who ordered her tying. She was manic and angry. After treatment by a senior D haka professor, we arranged micro-credit so that her brother and she could buy two cows and a cow shed. She called one cow 'chairman' and the other 'committee member'. Without the cows they could not afford medication and would not regain status in the village.

\section{Village doctors}

Partnership with the Bangladeshi Village Doctors' Welfare Association and individual village doctors has enabled us to make proposals for further investigation of the 'secret' of the Bangladeshi village, and of how villagers cope with people who are mentally ill. We have also been able to respond to requests for training, so that members of this association can help people in their villages affected by mental health problems. There are an estimated 200000 'village doctors' in Bangladesh. In spite of the objections of the MBBS-qualified doctors, such a training scheme was started about 30 years ago and was recognised by General Ershad when he became President of Bangladesh in 1983. Those in power had been impressed by the barefoot doctors' scheme in China as a way of bringing the benefits of allopathic medicine to village populations. As in China, the government no longer funds or controls such 'village doctors'. As in China, they have in more recent times been accused of doing harm, specifically by giving too many antibiotics or wrong treatments for diarrhoea. In China they were accused of spreading hepatitis through improperly washed syringes; this cannot happen in Bangladesh, as they cannot afford them.

There is evidence that such village doctors can improve the lives of many through their availability. The repeated phrase one hears in the villages and reads in new spaper articles is 'They do home visits at midnight'. A recent survey in Bangladesh found that $90 \%$ of villagers prefer village doctors to MBBS-qualified doctors. If a partnership could be forged between them and the regionally established departments of psychiatry at the medical schools, much more could be done.

In China, barefoot doctors do have acquaintance with Chinese as w ell as Western medicine. In Bangladesh, a background of alternative practice cannot be assumed. There is the widespread practice of homoeopathic medicine (another Western model) and Ayurvedic medicine (which is not). Both systems have training institutes in the country. Religious practices from local Islamic teachers using key verses from the Q ur'an are common, and some Hindu and Buddhist shrines are visited for faith healing. We have been told of a special 3-year training for hakims in raising and controlling jinns.

\section{Conclusion}

Apart from what can be learned to improve practice in the West, studies in Bangladeshi villages may be important for the future of the Bangladeshi mental health system. Eighty per cent of the population are still villagers. Some workers are suggesting that depression in men remaining in villages is a critical block to development. There needs to be caution about pathologising possible effects of oppression, but the suggestion needs study. Improved alternatives to mental hospital care for people with the behaviours of long-term major psychosis could start with augmenting the potential for containment and healing already present in villages. There is no benefits system, and no alternative to family care except for urban destitution or the one mental hospital, which is currently full. While the West is developing an expensive system of post-hospital care, countries like Bangladesh, which is among the ten poorest, could capitalise on their opportunity to develop their pre-hospital mental health care in a way that preserves better outcomes. 


\section{References}

Bhui, K. (2001) Epidemiology and social issues. In Psychiatry in Multicultural Britain (eds D. Bhugra \& R. Cochrane), pp. 49-74. London: Gaskell.

Chatterjee, S., Patel, V., Chatterjee, A., et al (2003) Evaluation of a community-based rehabilitation model for chronic schizophrenia in rural India. British Journal of Psychiatry, 182, 57-62.

Edgerton, R. B. \& Cohen, A. (1994) Culture and schizophrenia: the DOSMD challenge. British Journal of Psychiatry, $164,222-231$.

Halliburton, M. (2004) Finding a fit: psychiatric pluralism in South India and its implications for WHO studies of mental disorder. Transcultural Psychiatry, 41, 80-98.

H igginbotham, N . \& Marsella, A. J. (1988) International consultation and the homogenization of psychiatry in Southeast Asia. Social Science and Medicine, 27, 553-561.

Jablensky, A., Sartorius, N., Ernberg, G., et al (1992) Schizophrenia: manifestations, incidence and course in different cultures. Psychological Medicine (monograph supplement 20).

Kulhara, P. (1994) Outcome of schizophrenia: some transcultural observations with special reference to developing countries. European Archives of Psychiatry and Clinical Neurosciences, 244, 227-253.

Leff, J., Sartorius, N., Jablensky, A., et al (1990) The International Pilot Study of Schizophrenia: five year follow up findings. In Search for Causes of Schizophrenia, Vol. II (eds H. Haffner \& W. F. Guttaz). Berlin: Springer.

Lewis, A. (1953) Health as a social concept. British Journal of Sociology, 4, 109-124.

Peet, M. (2004) International variations in the outcome of schizophrenia and the prevalence of depression in relation to national dietary practices: an ecological analysis. British Journal of Psychiatry, 184, 404-408.

Radford, M. D. (2000) Getting the 'nuts' and the 'bolts' together. In At the Core of Mental Health Practice: Key Issues for Practitioners, Managers and Trainers (ed. D. Bailey). London: Pavilion.

Thara, R., Padmavati, R. \& Srinivasan, T. N. (2004) Focus on psychiatry in India. British Journal of Psychiatry, 184, 366-373.

Tooth, B., Kalyansunderaram, V. \& Glover, H. (1997) Recovery from Schizophrenia: A Consumer Perspective. Centre for Mental Health N ursing Research, Q ueensland University of Technology.

World Health Organization (1979) Schizophrenia: An International Follow-Up Study. Chichester: Wiley.

\title{
Traditional Chinese medicine in psychiatric practice in Singapore
}

\author{
Ee Heok Kua MBBS MD FRCPsych ${ }^{1}$ and Chay Hoon Tan MBBS PhD MMed (Psych) ${ }^{2}$
}

${ }^{1}$ Professor and Senior Consultant Psychiatrist, Department of Psychological Medicine, National University of Singapore, National University Hospital, 5 Lower Kent Ridge Road, Singapore 119074,

email pcmkeh@nus.edu.sg

${ }^{2}$ Associate Professor and Consultant Psychiatrist, Department of Pharmacology, National University of Singapore

round three-quarters of the Singaporean population are of $C$ hinese ethnic origin, and so traditional Chinese medicine is the most widely practised non-Western system of healthcare on the island.

Traditional Chinese medicine was first recorded some 2500 years ago in the ancient textbook of medicine Classics of Internal M edicine (H uang-Di N eijing), a collection of dialogues between the Yellow Emperor and his court physician, Ch'i Po. Written during the era of the Warring States (476-221 BCE), it showed an awareness of emotional and psychological factors in the causality of physical illness. A mind-body nexus rather than dichotomy was emphasised.

In Chinese culture, theories of health and illness are embedded in customs and religious philosophies. Religious beliefs and spirituality are therefore important issues in psychiatric practice. Since ancient times, religious practice and healing have been closely associated, and healing has often been performed by priests. $W$ ith advances in scientific knowledge, the healing role has now largely been taken over by doctors, but priests or traditional healers are still consulted first in many Chinese communities.

The basis of traditional Chinese medicine is the belief that there is a finely balanced relationship between bodily functions and emotions. This belief is built on the concept of 'yin-yang', a bipolarity that is opposite and complementary. The yin represents coldness and yang warmth. When this homoeostasis is disrupted, physical or mental illness can result. The prescription of herbal medicine or the administration of acupuncture attempts to restore the imbalance of the yin and yang. Besides physical treatment, it is the shared cultural beliefs of the healer and the patient and the relationship between these two that are pivotal in recovery.

\section{Health-seeking behaviour}

Family and cultural beliefs often determine illness behaviour and the health-seeking tendency of the patient. In a study of the illness behaviour of 100 Chinese patients referred consecutively to the psychiatric clinic of the $\mathrm{N}$ ational University Hospital in Singapore, it was found that 36 had also consulted traditional healers (Kua et al, 1993). Most of these patients were suffering from depression, anxiety or schizophrenia. It is common in the Chinese community to consult both the traditional healer and the psychiatrist.

The possession trance is a common culture-related phenomenon in Singapore and many other countries in Asia. The characteristic features have been reported by Kua (1986). Because possession trance is not deemed an illness in the community, a traditional healer is often
Family and cultural beliefs often determine illness behaviour and the healthseeking tendency of the patient. In a study of the illness behaviour of 100 Chinese patients referred consecutively to the psychiatric clinic of the National University Hospital in Singapore, it was found that 36 had also consulted traditional healers. 